\title{
Alkalibacillus silvisoli sp. nov., an alkaliphilic moderate halophile isolated from non-saline forest soil in Japan
}

\author{
Ron Usami, ${ }^{1}$ Akinobu Echigo, ${ }^{1}$ Tadamasa Fukushima, ${ }^{1}$ Toru Mizuki, ${ }^{1}$ \\ Yasuhiko Yoshida ${ }^{1}$ and Masahiro Kamekura ${ }^{2}$
}

Correspondence

Akinobu Echigo

dc0400017@toyonet.toyo.ac.jp

\author{
${ }^{1}$ Department of Applied Chemistry, Faculty of Engineering, and Bio-Nano Electronics Research \\ Centre, Toyo University, 2100 Kujirai, Kawagoe, Saitama 350-8585, Japan \\ ${ }^{2}$ Halophiles Research Institute, 677-1 Shimizu, Noda, Chiba 278-0043, Japan
}

Extremophiles are micro-organisms adapted to grow in conditions such as extreme $\mathrm{pH}$, temperature, salinity, hydrostatic pressure and ultraviolet and ionizing radiation (Horikoshi \& Grant, 1998; Rainey \& Oren, 2006). In general, it has been believed that they survive in the extreme environments in which they had adapted for growth. Many extremophiles, however, have been isolated from places in which they would not have been expected to grow. For example, alkaliphilic micro-organisms have been isolated from acidic soil samples ( $\mathrm{pH} 4.0)$ as well as from neutral and alkaline soils (Horikoshi, 1999). Halophilic micro-organisms are adapted to high levels of salinity and require a certain concentration of $\mathrm{NaCl}$ for optimum growth (Kushner \& Kamekura, 1988; Oren, 2002). They have been isolated from various saline environments such as salt lakes (e.g. the Dead Sea, the Great Salt Lake), salterns, solar salts and subsurface salt formations. It has been tacitly believed that halophilic micro-organisms able to grow in media containing more than $20 \%(\mathrm{w} / \mathrm{v})(3.4 \mathrm{M}) \mathrm{NaCl}$ are restricted to habitats in saline environments, and no reports

The GenBank/EMBL/DDBJ accession numbers for the 16S rRNA gene sequences of strains $\mathrm{BM}^{\top}$ and HN2 are AB264528 and AB267380, respectively. have been published showing the isolation of halophilic micro-organisms from samples of ordinary garden soil. Recently, we isolated many moderate halophiles from nonsaline soils in an area surrounding Tokyo, Japan, on agar plates of pH 9.5 containing $20.0 \% \mathrm{NaCl}$ (Echigo et al., 2005). A couple of alkaliphilic moderate halophiles have been reported so far. Bacillus oshimensis was isolated from a soil sample obtained in Hokkaido, Japan (Yumoto et al., 2005a), and Oceanobacillus oncorhynchi was isolated from the skin of a freshwater rainbow trout (Yumoto et al., 2005b). Both strains grew in medium containing 0-20\% $(\mathrm{w} / \mathrm{v}) \mathrm{NaCl}$, and optimal growth occurred at $\mathrm{pH}$ 9-10.

In this study, we isolated halophiles on agar plates containing $20.0 \% \mathrm{NaCl}$ ( $\mathrm{pH} 9.5$ ), and sequencing of the $16 \mathrm{~S}$ rRNA genes led to the suggestion that some of the isolates were closely related to species of the genus Alkalibacillus, which currently comprises three species, Alkalibacillus haloalkaliphilus (Fritze, 1996; Jeon et al., 2005), Alkalibacillus filiformis (Romano et al., 2005) and Alkalibacillus salilacus (Jeon et al., 2005). On the basis of the phylogenetic and phenotypic data obtained in this study, we propose that the moderately halophilic and alkaliphilic bacteria isolated from an ordinary non-saline forest soil sample represent a novel member of the genus Alkalibacillus. 
Soil samples were taken from ordinary non-saline forests in many places in Saitama Prefecture and Chiba Prefecture, Japan; there are no highly saline environments such as salterns or salt lakes in the region. The $\mathrm{NaCl}$ contents, calculated from the $\mathrm{Cl}^{-}$contents of soil extracts in water and determined using the method of Mohr (as described by Lenore et al., 1998), were less than $0.1 \%(\mathrm{w} / \mathrm{v})$. The soil extracts were slightly acidic ( $\mathrm{pH}$ 5.0-6.0).

A sample of soil (approx. $0.5 \mathrm{~g}$ ) was placed on an agar plate and spread with a spatula; the plate was then incubated in a plastic bag (to prevent desiccation) at $37^{\circ} \mathrm{C}$ for 3 weeks. The medium contained the following ingredients $\left(1^{-1}\right): 5.0 \mathrm{~g}$ Casamino acids (Difco), $5.0 \mathrm{~g}$ yeast extract (Difco), $1.0 \mathrm{~g}$ sodium glutamate monohydrate, $3.0 \mathrm{~g}$ trisodium citrate dihydrate, $2.0 \mathrm{~g} \mathrm{KCl}, 0.2 \mathrm{~g} \mathrm{MgSO}_{4} .7 \mathrm{H}_{2} \mathrm{O}, 36 \mathrm{mg}$ $\mathrm{FeCl}_{2} .4 \mathrm{H}_{2} \mathrm{O}, 200.0 \mathrm{~g}(3.4 \mathrm{M}) \mathrm{NaCl}$ and $20 \mathrm{~g}$ Bacto-agar (Difco). After autoclaving, the $\mathrm{pH}$ was adjusted to 9.5 by the addition of precalculated amounts of sterile $\mathrm{Na}_{2} \mathrm{CO}_{3}$ solution. Colonies $(0-8$, at most, per plate) were picked up, transferred to fresh agar plates, and subjected to dilution plating and subculturing on agar plates of the same medium in order to obtain pure cultures. Two strains, $\mathrm{BM} 2^{\mathrm{T}}$, which was isolated from a soil sample from Kawagoe, Saitama Prefecture, and strain HN2 (designated as no. 2 in Table 1 of Echigo et al., 2005), which was isolated from a soil sample from Yachiyo, Chiba Prefecture, were selected for further characterization after partial sequencing (about $500 \mathrm{bp}$ of the $5^{\prime}$ end) of PCR-amplified 16S rRNA genes from 29 isolates. The level of gene sequence similarity between strain $\mathrm{HN} 2$ and strain $\mathrm{BM} 2^{\mathrm{T}}$ was $99.2 \%$. In addition, DNA-DNA hybridization (assessed by using the fluorometric method of Ezaki et al., 1989) revealed high levels of relatedness (88 and $80 \%$ reciprocally), suggesting that strains $\mathrm{HN} 2$ and $\mathrm{BM} 2^{\mathrm{T}}$ strains should be classified within the same species.

Growth was determined by inoculating precultures of the strains into $100 \mathrm{ml}$ Erlenmeyer flasks containing $20 \mathrm{ml}$ liquid medium at different $\mathrm{NaCl}$ concentrations $[0,5.0,10.0$, 15.0, 20.0, 25.0 and $\left.30.0 \%(\mathrm{w} / \mathrm{v}) ; \mathrm{pH} 9.5,37^{\circ} \mathrm{C}\right], \mathrm{pH}$ values $[5.0,5.5,6.0,6.5,7.0,7.5,8.0,8.5,9.0,9.5$ and $10.0 ; 10.0 \%$ (w/v) $\left.\mathrm{NaCl}, 37^{\circ} \mathrm{C}\right]$ and temperatures $[20,30,37,40,50,60$ and $\left.70{ }^{\circ} \mathrm{C} ; 10.0 \%(\mathrm{w} / \mathrm{v}) \mathrm{NaCl}, \mathrm{pH} 9.5\right]$ and subjecting them to shaking at 120 r.p.m. Growth was monitored by taking $0.1 \mathrm{ml}$ culture periodically and measuring the optical density at $660 \mathrm{~nm}$.

Strain $\mathrm{BM} 2^{\mathrm{T}}$ grew at $\mathrm{NaCl}$ concentrations between 5.0 and $25.0 \%(\mathrm{w} / \mathrm{v})$, with optimal growth occurring at $10.0-15.0 \%$ $(\mathrm{w} / \mathrm{v})$. Growth of strain $\mathrm{BM} 2^{\mathrm{T}}$ occurred at $\mathrm{pH}$ 7.0-10.0, with an optimal growth occurring at $\mathrm{pH} 9.0-9.5$. The temperature range for growth extended from 20 to $50{ }^{\circ} \mathrm{C}$, with an optimum at $30-37^{\circ} \mathrm{C}$. Growth of strain $\mathrm{HN} 2$ occurred between 0 and $25.0 \%(\mathrm{w} / \mathrm{v}) \mathrm{NaCl}$, the optimum being at $5.0-10.0 \%(\mathrm{w} / \mathrm{v})$. The $\mathrm{pH}$ range for growth was $6.5-10.0$, with an optimum at $\mathrm{pH}$ 8.5-9.5. On agar plates containing $10.0 \%(\mathrm{w} / \mathrm{v}) \mathrm{NaCl}$, the colonies of both strains were cream in colour and opaque.
The following characterizations were performed on strain $\mathrm{BM} 2^{\mathrm{T}}$ only. The cells of this strain were rod-shaped, $0.3-0.5 \mu \mathrm{m}$ wide and $4.0-7.0 \mu \mathrm{m}$ long, and were motile by means of single polar flagella (when observed according to the method of Kodaka et al., 1982). Endospore formation was investigated after spore-staining had been performed according to the method of Wirtz-Conklin (as described by Murray et al., 1999). The cells of this strain were found to produce spherical terminal endospores within swollen sporangia on the isolation medium (containing $\mathrm{NaCl}$ at $10.0 \%, \mathrm{w} / \mathrm{v}$ ) at $37^{\circ} \mathrm{C}$. No gas vesicles were formed inside the cells. After fixation with acetic acid as described by Dussault (1955), cells from fresh cultures were Gram-positive but variable in old cultures. The $\mathrm{KOH}$ test and the L-alanine aminopeptidase test (Bactident aminopeptidase test strips; Merck) produced negative reactions, as was reported for Gram-positive bacteria (Gregersen, 1978). Anaerobic growth was not observed in an anaerobic jar (Echigo et al., 2005) after incubation for 7 days at $37^{\circ} \mathrm{C}$.

Acid production from carbohydrates was tested in basal medium containing $\left(1^{-1}\right) 1.0 \mathrm{~g}$ Casamino acids and $1.0 \mathrm{~g}$ yeast extract, supplemented with $10.0 \mathrm{~g}$ of the test carbohydrate; control cultures did not include the carbohydrates. The cultures were incubated at $37^{\circ} \mathrm{C}$ under aerobic conditions for 3 days; growth was determined visually and the $\mathrm{pH}$ was measured with a $\mathrm{pH}$ electrode. Strain $\mathrm{BM} 2^{\mathrm{T}}$ produced acid from D-galactose, maltose, sucrose, Dtrehalose and D-mannitol, but not from D-fructose, Dglucose or D-xylose.

Tests for catalase and oxidase activities and for the hydrolysis of starch, gelatin, casein, DNA, hippurate, aesculin, pullulan and Tween 80 were performed according to the procedures of Smibert \& Krieg (1994), Oren et al. (1997) and Schlesner et al. (2001). Strain BM2 ${ }^{\mathrm{T}}$ produced a positive catalase reaction and a negative oxidase reaction. Casein and gelatin were hydrolysed, but starch, DNA, hippurate, aesculin, pullulan and Tween 80 were not. Nitrate reduction was not detected with the method involving sulfanilic acid and an $\alpha$-naphthylamine reagent (Smibert \& Krieg, 1981) and gas formation from nitrate was not detected using Durham tubes under anaerobic conditions.

Sensitivity to antimicrobial agents was tested using antibiotic-impregnated filter-paper discs placed on a preinoculated plate of isolation medium containing $10.0 \%$ $(\mathrm{w} / \mathrm{v}) \mathrm{NaCl}$. Inhibitory zones around the discs were recorded after 3 days incubation at $37^{\circ} \mathrm{C}$. Strain $\mathrm{BM} 2^{\mathrm{T}}$ was sensitive to (per disc) ampicillin $(50 \mu \mathrm{g})$, bacitracin $(25 \mu \mathrm{g})$, tetracycline $(50 \mu \mathrm{g})$, streptomycin $(100 \mu \mathrm{g})$, novobiocin $(25 \mu \mathrm{g})$ and chloramphenicol $(25 \mu \mathrm{g})$ and resistant to kanamycin $(50 \mu \mathrm{g})$ and anisomycin $(50 \mu \mathrm{g})$.

HPLC analysis of isoprenoid quinones and GC/MS analysis of fatty acid methyl esters were performed with cells grown in isolation medium containing $10.0 \%(\mathrm{w} / \mathrm{v}) \mathrm{NaCl}$ at $30^{\circ} \mathrm{C}$ for 3 days according to the modified procedures of 
Table 1. Differential characteristics of strain $B M 2^{\top}$ and type strains of related Alkalibacillus species

Strains: $1, \mathrm{BM}^{\mathrm{T}}$; 2, A. haloalkaliphilus DSM 5271 ${ }^{\mathrm{T}}$; 3, A. filiformis DSM $15448^{\mathrm{T}}$; 4, A. salilacus DSM $16460^{\mathrm{T}}$. Data are from Fritze $(1996)$, Jeon et al. (2005), Romano et al. (2005) and the present study. +, Positive; -, negative; W, weak; DeMK, demethylmenaquinone.

\begin{tabular}{|c|c|c|c|c|}
\hline Characteristic & 1 & 2 & 3 & 4 \\
\hline Cell morphology & Long rods & Long rods & Long rods & Rods \\
\hline Colony pigmentation & Cream & $\begin{array}{c}\text { Creamy white } \\
\text { (with } 5-10 \% \mathrm{NaCl} \text { ) }\end{array}$ & $\begin{array}{l}\text { White to } \\
\text { transparent }\end{array}$ & Cream \\
\hline Motility & + & + & - & + \\
\hline Gram stain & + & - & + & + \\
\hline $\mathrm{KOH}$ test & - & - & + & - \\
\hline \multicolumn{5}{|c|}{$\mathrm{NaCl}$ concentration for growth (\%) } \\
\hline Range & $5.0-25.0$ & $>0$ to 25.0 & $0-18.0$ & $5.0-20.0$ \\
\hline Optimum & $10.0-15.0$ & $5.0-10.0^{\star}$ & 10.0 & $10.0-12.0$ \\
\hline \multicolumn{5}{|l|}{$\mathrm{pH}$ for growth } \\
\hline Range & $7.0-10.0$ & $>7$ to $>9.7$ & $7.0-10.0$ & $7.0-9.0$ \\
\hline Optimum & $9.0-9.5$ & 9.7 & 9.0 & 8.0 \\
\hline \multicolumn{5}{|l|}{ Temperature for growth $\left({ }^{\circ} \mathrm{C}\right)$} \\
\hline Range & $20-50$ & $<50$ & $15-45$ & $15-40$ \\
\hline Optimum & $30-37$ & $30-37^{\star}$ & 30 & 30 \\
\hline \multicolumn{5}{|l|}{ Acid production from: } \\
\hline D-Fructose & - & $-{ }^{*}$ & $-{ }^{*}$ & + \\
\hline D-Galactose & + & $-{ }^{*}$ & $-{ }^{*}$ & $-{ }^{*}$ \\
\hline Maltose & + & $-{ }^{*}$ & $-*$ & - \\
\hline D-Trehalose & + & $-*$ & $-*$ & - \\
\hline D-Mannitol & + & $-{ }^{\star}$ & $-{ }^{*}$ & - \\
\hline Catalase & + & + & $\mathrm{W}$ & + \\
\hline Oxidase & - & + & - & - \\
\hline \multicolumn{5}{|l|}{ Hydrolysis of: } \\
\hline Starch & - & W & - & - \\
\hline Casein & + & $-/ \mathrm{w}$ & - & - \\
\hline Gelatin & + & + & + & - \\
\hline Hippurate & - & + & - & $-*$ \\
\hline Aesculin & - & $+^{*}$ & $-*$ & + \\
\hline Nitrate reduction & - & - & - & + \\
\hline Sensitivity to streptomycin & + & $-^{*}$ & - & $-*$ \\
\hline DNA G $+C$ content $(\mathrm{mol} \%)$ & 37.0 & $37.0-38.0 \dagger$ & 39.5 & 41.0 \\
\hline Isoprenoid quinone(s) & MK-7 & MK-7 & MK-7, DeMK-6 & MK-7 \\
\hline Major fatty acid(s) & iso- $\mathrm{C}_{15: 0}$ & iso- $\mathrm{C}_{15: 0}$ & $\begin{array}{l}\text { iso- } \mathrm{C}_{15: 0} \\
\text { anteiso- } \mathrm{C}_{17: 0}\end{array}$ & $\begin{array}{l}\text { iso- }_{15: 0} \\
\text { anteiso- } C_{15: 0}\end{array}$ \\
\hline
\end{tabular}

${ }^{\star}$ Determined in this study using A. haloalkaliphilus JCM $12303^{\mathrm{T}}$, A. filiformis JCM $13893^{\mathrm{T}}$ or A. salilacus JCM $13894^{\mathrm{T}}$.

$\dagger$ Results from two different methods reported by Fritze (1996).

Tamaoka (1986) and Komagata \& Suzuki (1987). The predominant isoprenoid quinone of strain $\mathrm{BM} 2^{\mathrm{T}}$ was MK-7. The cellular fatty acid profile of strain $B M 2^{\mathrm{T}}$ was characterized by the presence of saturated branched fatty acids such as iso- $\mathrm{C}_{15: 0}(42 \%)$, anteiso- $\mathrm{C}_{17: 0}(20 \%)$, anteiso- $\mathrm{C}_{15: 0}(6 \%)$, iso- $\mathrm{C}_{16: 0}(6 \%)$, iso- $\mathrm{C}_{17: 0}(6 \%)$ and anteiso- $\mathrm{C}_{16: 0}(3 \%)$, which was in accord with reported profiles of Alkalibacillus species (Fritze, 1996; Jeon et al., 2005; Romano et al., 2005).

Preparation of the peptidoglycan and the determination of its structure were performed according to the modified procedures of Schleifer \& Kandler (1972), Schleifer (1985) and Schlesner et al. (2001). The purified peptidoglycan was hydrolysed in $4 \mathrm{M} \mathrm{HCl}$ at $100{ }^{\circ} \mathrm{C}$ for $16 \mathrm{~h}$ (total hydrolysate) or $45 \mathrm{~min}$ (partial hydrolysate). Diamino acids were identified from the total hydrolysate by one-dimensional TLC in methanol/pyridine/4 M HCl/water (80:10:4:26, by vol.). Amino acids and peptides were identified from the partial hydrolysate by using two-dimensional TLC. The first direction was developed in isopropanol/acetic acid/water ( $75: 10: 15$, by vol.) and the second in $\alpha$-dipicolin $/ 25 \%$ ammonium hydrate/water $(70: 2: 28$, by vol.). The resulting fingerprints were compared with those from known 
peptidoglycan structures. The peptidoglycan structure of strain $\mathrm{BM} 2{ }^{\mathrm{T}}$ belonged to the $\mathrm{A} 1 \gamma$ type, and the diamino acid was meso-diaminopimelic acid, as in all Alkalibacillus species (Fritze, 1996; Jeon et al., 2005; Romano et al., 2005).

Total DNAs of strain $\mathrm{BM} 2^{\mathrm{T}}$ were extracted by the method of Saito \& Miura (1963). The 16S rRNA genes were amplified by PCRs with the following forward and reverse primers: 5'-AGAGTTTGATCCTGGCTCAG-3' (positions 8-27 according to Escherichia coli numbering) and 5'-GGCTACCTTGTTACGACTT-3' (positions 1510-1492). The amplified DNAs were cloned by using the TA cloning kit (Invitrogen) and were sequenced using the ABI PRISM BigDye Terminator v3.1 cycle sequencing kits (Applied Biosystems) with the following primers: 5'-GGAAACAGCTATGACCATG-3' (vector side), 5' -GACTACCAGGGTATCTAATC-3' (positions 805-786), 5' -AGGGTTGCGCTCGTTG-3' (positions 1115-1100) and 5'-GTAAAACGACGGCCAGT-3' (vector side) on an ABI PRISM 310 Genetic Analyzer (Applied Biosystems). There was little heterogeneity (two to three bases) among the sequences (1492 bp) of several clones. The sequences determined and those of related strains retrieved from the DNA Database of Japan (Miyazaki et al., 2003; Pearson \& Lipman, 1988; Lipman \& Pearson, 1985) were aligned using the CLUSTAL W multiple sequence alignment program (Thompson et al., 1994). The phylogenetic tree was constructed using the neighbourjoining method (Saitou \& Nei, 1987) and evaluated by bootstrap resampling using 1000 datasets (Felsenstein, 1985). The phylogenetic analysis showed that strain $\mathrm{BM} 2^{\mathrm{T}}$ was a member of the family Bacillaceae, being most closely related to the type strains of A. haloalkaliphilus $(98.0 \%$ sequence similarity), A. filiformis ( $97.8 \%$ sequence similarity) and A. salilacus (95.9\% sequence similarity) (Fig. 1).

The $\mathrm{G}+\mathrm{C}$ content of total DNA of strain $\mathrm{BM} 2^{\mathrm{T}}$ (determined using the HPLC method of Tamaoka \& Komagata, 1984) was $37.0 \mathrm{~mol} \%$, which is similar to values reported for $A$. haloalkaliphilus, A. filiformis and A. salilacus (37.0-38.0, 39.5 and $41.0 \mathrm{~mol} \%$, respectively) (Fritze, 1996; Jeon et al., 2005; Romano et al., 2005).

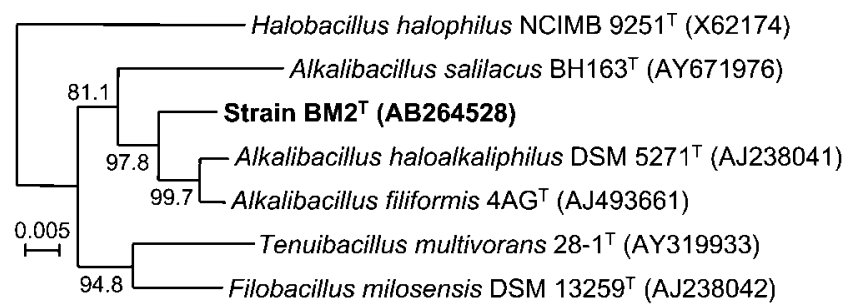

Fig. 1. Neighbour-joining phylogenetic tree, based on $16 \mathrm{~S}$ rRNA gene sequences, showing the relationships of strain $\mathrm{BM}^{\top}{ }^{\top}$ and related strains. Bootstrap values, shown at branch nodes, are expressed as percentages of 1000 replicates. Halobacillus halophilus NCIMB $9251^{\top}$ was used as an outgroup. Bar, 0.005 changes per nucleotide position.
DNA-DNA hybridization between strain $\mathrm{BM} 2^{\mathrm{T}}$ and closely related species was assessed by using the fluorometric method of Ezaki et al. (1989). The results showed low levels of relatedness for strain $\mathrm{BM} 2^{\mathrm{T}}$ with respect to A. haloalkaliphilus JCM $12303^{\mathrm{T}}$ (23 and $16 \%$ reciprocally), A. filiformis JCM $13893^{\mathrm{T}}$ (25 and $21 \%$ reciprocally) and A. salilacus JCM $13894^{\mathrm{T}}$ (27 and $19 \%$ reciprocally).

These phenotypic and genotypic data suggest that the strain $\mathrm{BM} 2{ }^{\mathrm{T}}$ belongs to the genus Alkalibacillus (Jeon et al., 2005). In terms of phenotypic properties, there are differences between strain $\mathrm{BM} 2^{\mathrm{T}}$ and the three aforementioned species of the genus Alkalibacillus, as summarized in Table 1. Strain $\mathrm{BM} 2^{\mathrm{T}}$ was more halophilic than those three species, produced acid from many carbohydrates and showed sensitivity to streptomycin. Other differences between strain $\mathrm{BM} 2^{\mathrm{T}}$ and A. haloalkaliphilus, the most closely related species, include the $\mathrm{pH}$ range for growth, the temperature range for growth, Gram staining, the oxidase reaction and the results for starch hydrolysis and hippurate hydrolysis. Both the low levels of DNA-DNA relatedness and the phenotypic differences between strain $\mathrm{BM} 2^{\mathrm{T}}$ and the three recognized Alkalibacillus species indicated that the $\mathrm{BM} 2^{\mathrm{T}}$ represents a novel species of the genus Alkalibacillus, for which the name Alkalibacillus silvisoli sp. nov. is proposed.

\section{Description of Alkalibacillus silvisoli sp. nov.}

Alkalibacillus silvisoli (sil.vi.so'li. L. n. silva forest; L. n. solum soil; N.L. gen. n. silvisoli of forest soil, the source of isolation of the type strain).

Cells are rod-shaped, $0.3-0.5 \times 4.0-7.0 \mu \mathrm{m}$ in size and motile by means of single polar flagella. Spores are spherical and located terminally in swollen sporangia. Gram-positive in fresh culture but variable in old culture. Negative results are obtained in the $\mathrm{KOH}$ test and for L-alanine aminopeptidase. Peptidoglycan is of the A $1 \gamma$ type, and the diamino acid is meso-diaminopimelic acid. Colonies on agar plates are cream in colour and opaque. Growth occurs at $\mathrm{NaCl}$ concentrations between 5.0 and $25.0 \%(\mathrm{w} / \mathrm{v})$, with optimal growth at $10.0-15.0 \%(\mathrm{w} / \mathrm{v})$. Growth occurs at $\mathrm{pH} 7.0$ 10.0, the optimal pH being 9.0-9.5. Growth is observed at temperatures in the range $20-50{ }^{\circ} \mathrm{C}$, the optimum being at $30-37^{\circ} \mathrm{C}$. Anaerobic growth is not observed. Acid is produced from D-galactose, maltose, sucrose, D-trehalose and D-mannitol, but not from D-fructose, D-glucose or Dxylose. Catalase-positive and oxidase-negative. Hydrolysis of casein and gelatin is detected, but not for starch, DNA, hippurate, aesculin, pullulan or Tween 80. Reduction of nitrate and gas formation are not observed. Sensitive to ampicillin, bacitracin, tetracycline, streptomycin, novobiocin and chloramphenicol but resistant to kanamycin and anisomycin. The G+C content of total DNA is $37.0 \mathrm{~mol} \%$. The predominant isoprenoid quinone is MK-7. The major cellular fatty acids are iso- $\mathrm{C}_{15: 0}(42 \%)$, anteiso- $\mathrm{C}_{17: 0}$ $(20 \%)$, anteiso- $\mathrm{C}_{15: 0}(6 \%)$, iso- $\mathrm{C}_{16: 0}(6 \%)$, iso- $\mathrm{C}_{17: 0}$ $(6 \%)$ and anteiso- $\mathrm{C}_{16: 0}(3 \%)$. 
The type strain, $\mathrm{BM} 2^{\mathrm{T}}\left(=\mathrm{JCM} 14193^{\mathrm{T}}=\mathrm{DSM} 18495^{\mathrm{T}}\right)$, was isolated from non-saline surface soil from a forest in Kawagoe, Saitama Prefecture, Japan. A reference strain, $\mathrm{HN} 2$, was isolated from non-saline surface soil from a forest in Yachiyo, Chiba Prefecture, Japan.

\section{Acknowledgements}

We are grateful to Yuichi Nogi and Masayuki Miyazaki (JAMSTEC, Yokosuka, Japan) for their help with the DNA-DNA hybridization experiments. Part of this study was supported by a grant for the 21 st Century's Center of Excellence programmes, organized by the Ministry of Education, Culture, Sports, Science and Technology (Japan) since 2003, and by the Research Fellowships of Japan Society for the Promotion of Science for Young Scientists (to A. E.).

\section{References}

Dussault, H. P. (1955). An improved technique for staining red halophilic bacteria. J Bacteriol 70, 484-485.

Echigo, A., Hino, M., Fukushima, T., Mizuki, T., Kamekura, M. \& Usami, R. (2005). Endospores of halophilic bacteria of the family Bacillaceae isolated from non-saline Japanese soil may be transported by Kosa event (Asian dust storm). Saline Systems 1, 8. doi:10.1186/ 1746-1448-1-8

Ezaki, T., Hashimoto, Y. \& Yabuuchi, E. (1989). Fluorometric deoxyribonucleic acid-deoxyribonucleic acid hybridization in microdilution wells as an alternative to membrane filter hybridization in which radioisotopes are used to determine genetic relatedness among bacterial strains. Int J Syst Bacteriol 39, 224-229.

Felsenstein, J. (1985). Confidence limits on phylogenies: an approach using the bootstrap. Evolution 39, 783-791.

Fritze, D. (1996). Bacillus haloalkaliphilus sp. nov. Int J Syst Bacteriol 46, 98-101.

Gregersen, T. (1978). Rapid method for distinction of gramnegative from gram-positive bacteria. Eur J Appl Microbiol Biotechnol 5, 123-127.

Horikoshi, K. (1999). Alkaliphiles: some applications of their products for biotechnology. Microbiol Mol Biol Rev 63, 735-750.

Horikoshi, K. \& Grant, W. D. (1998). Extremophiles - Microbial life in Extreme Environments. New York: Wiley-Liss.

Jeon, C. O., Lim, J. M., Lee, J. M., Xu, L. H., Jiang, C. L. \& Kim, C. J. (2005). Reclassification of Bacillus haloalkaliphilus Fritze 1996 as Alkalibacillus haloalkaliphilus gen. nov., comb. nov. and the description of Alkalibacillus salilacus sp. nov., a novel halophilic bacterium isolated from a salt lake in China. Int J Syst Evol Microbiol 55, 1891-1896.

Kodaka, H., Armfield, A. Y., Lombard, G. L. \& Dowell, V. R., Jr (1982). Practical procedure for demonstrating bacterial flagella. J Clin Microbiol 16, 948-952.

Komagata, K. \& Suzuki, K. (1987). Lipid and cell-wall analysis in bacterial systematics. Methods Microbiol 19, 161-207.

Kushner, D. J. \& Kamekura, M. (1988). Physiology of halophilic eubacteria. In Halophilic Bacteria, vol. 1, pp. 109-140. Edited by F. Rodriguez-Valera. Boca Raton FL: CRC Press.

Lenore, S. C., Arnold, E. G. \& Andrew, D. E. (1998). Standard Methods for the Examination of Water and Wastewater, 20th edn. Washington, DC: American Public Health Association/American Water Works Association/Water Environment Federation.
Lipman, D. J. \& Pearson, W. R. (1985). Rapid and sensitive protein similarity searches. Science 227, 1435-1441.

Miyazaki, S., Sugawara, H., Gojobori, T. \& Tateno, Y. (2003). DNA Data Bank of Japan (DDBJ) in XML. Nucleic Acids Res 31, 13-16.

Murray, P. R., Baron, E. J., Pfaller, M. A., Tenover, F. C. \& Yolken, R. H. (1999). Manual of Clinical Microbiology, 7th edn. Washington, DC: American Society for Microbiology.

Oren, A. (2002). Halophilic Microorganisms and their Environments. Dordrecht: Kluwer.

Oren, A., Ventosa, A. \& Grant, W. D. (1997). Proposed minimal standards for description of new taxa in the order Halobacteriales. Int J Syst Bacteriol 47, 233-238.

Pearson, W. R. \& Lipman, D. J. (1988). Improved tools for biological sequence comparison. Proc Natl Acad Sci U S A 85, 2444-2448.

Rainey, F. A. \& Oren, A. (editors) (2006). Methods in Microbiology, vol. 35, Extremophiles. New York: Academic Press.

Romano, I., Lama, L., Nicolaus, B., Gambacorta, A. \& Giordano, A. (2005). Alkalibacillus filiformis sp. nov., isolated from a mineral pool in Campania, Italy. Int J Syst Evol Microbiol 55, 2395-2399.

Saito, H. \& Miura, K. (1963). Preparation of transforming deoxyribonucleic acid by phenol treatment. Biochim Biophys Acta 72, 619-629.

Saitou, N. \& Nei, M. (1987). The neighbor-joining method: a new method for reconstructing phylogenetic trees. Mol Biol Evol 4, 406-425.

Schleifer, K. H. (1985). Analysis of the chemical composition and primary structure of murein. Methods Microbiol 18, 123-156.

Schleifer, K. H. \& Kandler, O. (1972). Peptidoglycan types of bacterial cell walls and their taxonomic implications. Bacteriol Rev 36, 407-477.

Schlesner, H., Lawson, P. A., Collins, M. D., Weiss, N., Wehmeyer, U., Völker, H. \& Thomm, M. (2001). Filobacillus milensis gen. nov., sp. nov., a new halophilic spore-forming bacterium with Orn-D-Glutype peptidoglycan. Int J Syst Evol Microbiol 51, 425-431.

Smibert, R. M. \& Krieg, N. R. (1981). General characterization. In Manual of Methods for General Microbiology, pp. 409-443. Edited by P. Gerhardt, R. G. E. Murray, R. N. Costilow, E. W. Nester, W. A. Wood, N. R. Krieg \& G. B. Phillips. Washington, DC: American Society for Microbiology.

Smibert, R. M. \& Krieg, N. R. (1994). Phenotypic characterization. In Methods for General and Molecular Bacteriology, pp. 607-654. Edited by P. Gerhardt, R. G. E. Murray, W. A. Wood \& N. R. Krieg. Washington, DC: American Society for Microbiology.

Tamaoka, J. (1986). Analysis of bacterial menaquinone mixtures by reverse-phase high-performance liquid chromatography. Methods Enzymol 123, 251-256.

Tamaoka, J. \& Komagata, K. (1984). Determination of DNA base composition by reverse-phase high-performance liquid chromatography. FEMS Microbiol Lett 25, 125-340.

Thompson, J. D., Higgins, D. G. \& Gibson, T. J. (1994). CLUSTAL W: improving the sensitivity of progressive multiple sequence alignment through sequence weighting, position-specific gap penalties and weight matrix choice. Nucleic Acids Res 22, 4673-4680.

Yumoto, I., Hirota, K., Goto, T., Nodasaka, Y. \& Nakajima, K. (2005a). Bacillus oshimensis sp. nov., a moderately halophilic, non-motile alkaliphile. Int J Syst Evol Microbiol 55, 907-911.

Yumoto, I., Hirota, K., Nodasaka, Y. \& Nakajima, K. (2005b). Oceanobacillus oncorhynchi sp. nov., a halotolerant obligate alkaliphile isolated from the skin of a rainbow trout (Oncorhynchus mykiss), and emended description of the genus Oceanobacillus. Int J Syst Evol Microbiol 55, 1521-1524. 